\title{
Pemanfaatan Model Belajar Window Shopping Dalam Upaya Peningkatan Hasil Belajar
}

\author{
Angga Dwi Prasetyo ${ }^{*}$ \\ ${ }^{1}$ Pendidikan Guru Madrasah Ibtidaiyah, Fakultas Ilmu Tarbiyah, UIN Raden Mas Said \\ Surakarta, Indonesia
}

e-mail corresponden : angga.dwiprasetyo@iain-surakarta.ac.id

\begin{abstract}
ABSTRAK
Model pembelajaran merupakan representasi maupun rencana yang digunakan dalam proses belajar dan mengajar oleh guru maupun siswa untuk mencapai tujuan pendidikan menggunakan pola/ prosedur yang sistematis. Berdasarkan skor Trends In International Mathematics and Science Study (TIMSS) dan Programme for International Student Assessment (PISA) tahun 2018 I ndonesia menempati peringkat dalam kategori rendah dalam hal literasi sains dan kemampuan sains sehingga dibutuhkan terobosan yang baru dalam pembelajaran, sehingga diperlukan suatu model pembelajaran yang interaktif agar membuat suasana belajar menjadi menyenangkan, salah satunya model pembelajaran tipe windows shopping. Tujuan penelitian melihat pengaruh penerapan model windows shopping terhadap ketuntasan belajar dan peningkatan hasil belajar peserta didik, metode yang digunakan quassy experiment dengan pengambilan sampel secara purposive sampling dan analisis data menggunakan uji N-gain. Hasil penelitian menunjukkan model pembelajaran windows shopping pada materi konsep dasar IPA dapat meningkatkan hasil belajar sebesar 0,78 yang termasuk kategori tinggi dibandingkan kelas kontrol. Selain itu penerapan model pembelajaran windows shopping juga dapat meningkatkan angka ketuntasan belajar pada peserta didik. Berdasarkan hasil penelitian didapatkan model pembelajaran windows shopping dapat meningkatkan hasil belajar peserta didik pada materi konsep dasar IPA.
\end{abstract}

Kunci Kunci : Konsep Dasar IPA; Hasil Belajar; Windows Shopping

\begin{abstract}
The learning model is a representation and plan used in the teaching and learning process by teachers and students to achieve educational goals using systematic patterns / procedures. Based on the scores of Trends In International Mathematics and Science Study (TIMSS) and the Program for International Student Assessment (PISA) 2018, Indonesia is ranked in the low category in terms of scientific literacy and scientific abilities so that new breakthroughs are needed in learning, so a learning model is needed. which is interactive in order to make the learning atmosphere fun, one of which is the windows shopping type of learning model. The research objective was to see the effect of the application of the windows shopping model on learning completeness and the improvement of student learning outcomes. The method used was a quassy experiment with purposive sampling and data analysis using the $N$-gain test. The results showed that the windows shopping learning model on the basic concepts of science can improve learning outcomes by 0.78 which is in the high category compared to the control class. In addition, the application of the windows shopping learning model can also increase the learning completeness rate of students. Based on the research results, it was found that the windows shopping learning model can improve student learning outcomes in the basic concepts of science material.
\end{abstract}

Keyword : Basic Concepts of Science; Learning Outcomes; Windows Shopping 


\section{PENDAHULUAN}

Matakuliah Konsep Dasar IPA merupakan matakuliah wajib yang harus dikuasai mahasiswa pendidikan guru madrasah ibtidaiyah Institut Agama Islam Negeri Surakarta semester empat, matakuliah ini terdiri dari banyak materi tentang makhluk hidup, benda maupun gejala alam disekitar kehidupan seharihari. Berdasarkan fakta-fakta dikelas pada pembelajaran matakuliah ini masih banyak mahasiswa yang memiliki nilai rendah maupun tidak tuntas dalam memenuhi nilai minimum kelulusan, hal ini disebabkan pada saat pembelajaran masih banyak mahasiswa yang kurang fokus pada materi yang diberikan karena penyampaian materi yang menggunakan model konvensional, pada saat presentasi masih banyak mahasiswa yang menampilkan powerpoint berupa tulisan semua dan sedikit gambar maupun point-point materi, siswa yang kurang aktif dalam diskusi dan beberapa siswa mendominasi dalam diskusi serta materi yag terlalu banyak membuat mahasiswa jenuh dalam proses pembelajaran. Hal ini menuntut pendidik untuk dapat membuat suasana pembelajaran menjadi menarik dan tidak membosankan sehingga mahasiswa dapat memahami dengan baik materi yang disampaikan oleh pendidik, salah satunya dengan menggunakan model pembelajaran (Yustiqvar et al., 2019).

Model pembelajaran merupakan representasi maupun rencana yang digunakan dalam proses belajar dan mengajar oleh guru maupun siswa untuk mencapai tujuan pendidikan menggunakan pola/ prosedur yang sistematis. Tujuan pendidikan sendiri ialah meningkatkan kesejahteraan umum dan mencerdaskan kehidupan bangsa serta membentuk peserta didik menjadi warga negara yang demokrasi, manusia beriman dan bertakwa serta memiliki akhlak mulia, kreatif, mandiri, serta bertanggung jawab menurut Undang-Undang Pendidikan No. 20 tahun 2003 (Wihartanti, 2017).

Pendidikan memiliki makna berupa usaha sadar pendidik maupun instansi pendidikan untuk membuat suasana transfer ilmu dari pendidik kepada peserta didik menyenangkan demi meningkatkan kualitas peserta didik agar terwujudnya tujuan pendidikan, dalam mencapai tujuan tentunya mahasiswa dalam konteks ini harus menguasai materi matakuliah yang diberikan yaitu konsep dasar IPA, dimana pada konsep dasar IPA terdapat banyak sub materi yang harus dikuasi oleh mahasiswa agar dapat lulus dengan nilai yang memuaskan, selain itu pembelajaran konsep dasar IPA dapat pmeningkatkan kemampuan mahasiswa yang nantinya akan menjadi calon pendidik dalam hal menyangkut cara kerja, kemampuan berpikir kritis, serta cara memecahkan masalah (Sujana, 2014). Sehingga pembelajaran konsep dasar IPA menjadi penting untuk dipelajari peserta didik untuk menumbuhkan kemampuan berpikir kritis pada peserta didik (Ramdani et al., 2020).

Indonesia berdasarkan penilaian dalam kategori kemampuan siswa bidang 
matematika dan sains di dunia masih terbilang rendah, hal ini dikuatkan oleh hasil pengukuran Trends In International Mathematics and Science Study (TIMSS) atau kecenderungan pembelajaran sains dan matematika internasional pada tahun 2015 yang menunjukkan bahwa Indonesia berada di peringkat 46 dari 51 negara dengan skor 397, hal ini menunjukkan kemampuan siswa Indonesia masih sangat tertinggal dibandingkan negara lain, oleh karena itu hal ini menjadi fokus utama dalam bidang Pendidikan untuk memperbaiki kualitas Pendidikan di Indonesia. Selain itu kurangnya minat dan tingkat literasi membaca siswa Indonesia menjadi salah satu penyebab rendahnya kemampuan siswa Indonesia di bidang sains dan matematika, hal ini ditunjukkan dari penilaian kemampuan membaca, sains dan matematika oleh Programme for International Student Assessment (PISA) tahun 2018, Indonesia berada di peringkat 74 dari 79 negara (Dickey, 2018). Sehingga diperlukan suatu trobosan baru dalam proses belajar mengajar agar mahasiswa menjadi aktif dikelas selama pembelajaran sehingga menumbuhkan rasa percaya diri siswa, minat belajar dan kemampuan berpikir dari siswa, terdapat model pembelajaran kooperatif yang menempatkan siswa sebagai pusat pembelajaran sehingga terjalinnya interaksi antar peserta didik yang dapat meningkatkan hasil belajar (Jarre \& Bachtiar, 2017), salah satunya model pembelajaran windows shopping.

Model pembelajaran windows shopping terdiri dari kata windows yang artinya jendela dan shopping yang berarti belanja, model pembelajran ini termasuk pembelajaran kooperatif dengan mengangkat kegiatan untuk melihat dan memahami buah pikir seseorang maupun sebaliknya, pada model pembelajaran ini dua mahasiswa akan bertindak menjadi tutor sebaya dengan menjelaskan hasil diskusi materi yang ditampilkan dalam bentuk karya yang akan dipajang dan dijelaskan pada mahasiswa yang lain, sementara anggota kelompok yang lain akan melakukan shopping atau berkunjung ketempat kelompok lain untuk mendengarkan dan mencatat materi yang disampaikan dari hasil diskusi kelompok yang lain hal ini terjadi berulang hingga masing-masing kelompok kembali pada kelompoknya dan menjelaskan hasil materi yang didapatkan kepada dua orang anggota kelompok yang berperan sebagai tutor, sehingga semua kelompok mendapatkan informasi yang sama dari semua materi yang didiskusikan masing-masing kelompok (Rasidi \& Nuruddin, 2019).

Pada model pembelajaran ini, pendidik berperan sebagai fasilitator untuk memberikan informasi sebelum melakukan model pembelajaran dan melihat serta mengatur agar proses model pembelajaran berjalan dengan lancer dan membantu mahasiswa jika mengalami kesulitan dalam menjelaskan dan memberikan arahan jika ada mahasiswa yang mengalami miskonsepsi terhadap materi yang diberikan (Nurdjannah et al., 2019).

Hasil penelitian menggunakan aplikasi strategi dan berbagai metode dalam proses pembelajaran di kelas yang 
dilakukan oleh Yetti (2018), Nurdjannah et al., (2019) dan Riyanto (2019), secara umum menunjukkan terdapat peningkatan kemampuan berpikir dan peningkatan hasil belajar peserta didik menggunakan strategi dan model pembelajaran dibandingkan dengan metode konvensional. Sehingga diharapkan metode windows shopping pada materi konsep dasar IPA dapat meningkatkan hasil belajar.

\section{METODE PENELITIAN}

Pada penelitian ini menggunakan metode Quasy Experiment dengan PretestPosttest Design sebagai rancangan penelitiannya(Sugiyono, 2014; 2015). Data diperoleh dari sampel mahasiswa semester empat pendidikan guru madrasah ibtidaiyah IAIN Surakarta. Terdapat dua sampel pada penelitian ini, yaitu kelas 4A dengan jumlah 20 mahasiswa (sebagai kontrol) dan 20 mahasiswa dari kelas 4B (aplikasi model pembelajaran windows shopping). Sampel diambil menggunakan teknik purposive sampling. Pengukuran peningkatan hasil belajar peserta didik meliputi hasil belajar utama pada ranah kognitif, ranah afektif dan psikomotorik sebagai pendukung.

Analisis kenaikan hasil belajar menggunakan uji N-gain. Analisis data ranah pendukung menggunakan analisis deskriptif. Hasil belajar peserta didik dikatakan efektif apabila $\geq 80 \%$ mencapai kriteria ketuntasan minimal (KKM) sebesar 75, Terdapat kenaikan hasil belajar (NGain) pada kelas perlakuan $\geq 70 \%$ (Zumroh et al., 2018). Indikator keberhasilan dicapai apabila terdapat peningkatan hasil belajar, peningkatan rata-rata skor hasil belajar, peningkatan ketuntasan belajar dan terjadi perubahan sikap yang mengacu pada peningkatan aktivitas belajar.

\section{HASIL DAN PEMBAHASAN}

\section{Hasil Penelitian}

Pembelajaran diawali dengan pembukaan oleh dosen selanjutnya dosen melakukan refreshing terhadap materi yang akan disampaikan secara ringkas selanjutnya dilakukan oengambilan data berupa pretest guna melihat terlebih dahulu pengetahuan mahasiswa secara mendasar, selanjutnya dosen membagi mahasiswa menjadi empat kelompok dan memberitahukan prosedur dalam model pembelajaran windows shopping, masingmasing kelompok diberikan kertas karton dan spidol warna untuk menuangkan hasil diskusi dalam bentuk gambar dan peta konsep, dosen memberikan waktu 15 menit untuk mahasiswa berdiskusi dan menyiapkan bahan yang akan disajikan pada saat pembelajaran windows shopping, dan waktu 25 menit untuk melakukan kegiatan berkunjung kepada masingmasing kelompok demi mencatat materi dari tiap kelompok serta 10 menit untuk diskusi dan menarik kesimpulan dari hasil kuliah menggunakan model pembelajaran windows shopping, pada akhir jam pelajaran dilakukan post-test.

Pada kelas kontrol dosen memberikan awalan dan melakukan pretest serta penyampaian materi dilakukan secara konvensional menggunakan powerpoint 
PEDAGOGIKA

Volume 12 (Nomor 2) 2021

HaL. $184-193$

dan selanjutnya diadakan diskusi tanya jawab dengan dosen, pada akhir jam pelajaran dilakukan post-test. Kegiatan belajar menggunakan model pembelajaran windows shopping disajikan pada gambar 1 .

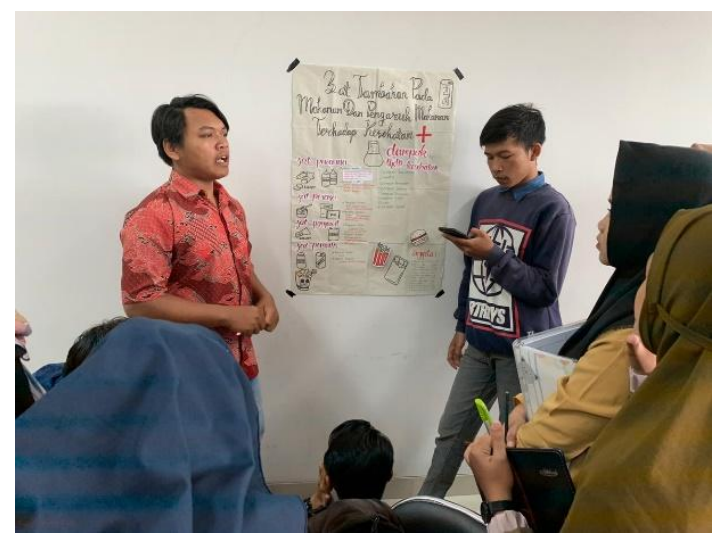

Gambar 1. Kegiatan model pembelajaran windows shopping materi komsep dasar IPA

Data hasil pretest yang didapatkan pada kelas kontrol maupun perlakuan selanjutnya dilakukan analisis untuk mengetahui perbandingan ketuntasan belajar dan persentase distribusi jumlah ketuntasan belajar dari mahasiswa kelas kontrol maupun kelas perlakukan model pembelajaran dengan membandingkan rata-rata hasil pretest terhadap nilai ketentuan ketuntasan minimum (KKM). Data distribusi, jumlah sampel dan persentase kategori ketuntasan belajar kelas kontrol dan perlakuan model pembelajaran windows shopping disajikan pada tabel 1.

Suatu model pembelajaran dapat dikatan efektif jika mampu meingkatkan ketuntasan belajar pada peserta didik dan membantu dalam peningkatan hasil belajar pada peserta didik, dalam penelitian ini peningkatan hasil belajar pada peserta didik diukur menggunakan analisis uji $\mathrm{N}$ gain, dimana nilai $\mathrm{N}$ gain dapat menjelaskan adanya peningkatan pada proses pembelajaran, yaitu pada pembelajaran konvensional maupun menggunakan model pembelajaran windows shopping, hasil analisis pengukuran peningkatan hasil belajar menggunakan $\mathrm{N}$ gain disajikan pada tabel 2 .

Tabel 1. Distribusi, jumlah sampel dan persentase kategori ketuntasan belajar materi konsep dasar IPA

\section{Pedagogika.fip@ung.ac.idＰ-ISSN: 2086-4469Ｅ-ISSN: 2716-0580}




\begin{tabular}{cccccccccc}
\hline & & \multicolumn{3}{c}{ Pretest } & \multicolumn{3}{c}{ Post-test } & \multicolumn{3}{c}{ Pretest } & Post-test \\
\cline { 2 - 9 } & & $\sum \mathrm{S}$ & $\%$ & $\sum \mathrm{S}$ & $\%$ & $\sum \mathrm{S}$ & $\%$ & $\sum \mathrm{S}$ & $\%$ \\
\hline $\begin{array}{c}\text { Tidak } \\
\text { Tuntas }\end{array}$ & $0-64$ & 15 & 75 & 4 & 20 & 14 & 70 & 0 & 0 \\
\hline Tuntas & $65-$ & 5 & 25 & 16 & 80 & 6 & 30 & 20 & 100 \\
& 100 & & & & & & & & \\
\hline \multicolumn{2}{c}{ Jumlah } & 20 & 100 & 20 & 100 & 20 & 100 & 20 & 100 \\
\hline
\end{tabular}

Tabel 2. Hasil nilai $\mathbf{N}$ gain peserta didik pada materi konsep dasar IPA

\begin{tabular}{cccccc}
\hline & $\begin{array}{c}\text { Rerata } \\
\text { K- }\end{array}$ & & \multicolumn{3}{c}{ Jumlah Siswa yang } \\
Kelas & $\begin{array}{c}\text { Mendapatkan N gain } \\
\text { gain }\end{array}$ & Kriteria & \multicolumn{3}{c}{ Mendah } \\
\cline { 3 - 5 } & & & Tinggi & Sedang & Rendah \\
\hline Kelas & 0,55 & Sedang & $20 \%$ & $70 \%$ & $10 \%$ \\
Kontrol & & & & & \\
\hline $\begin{array}{c}\text { Kelas } \\
\text { Perlakuan }\end{array}$ & 0,78 & Tinggi & $70 \%$ & $30 \%$ & $0 \%$ \\
\hline
\end{tabular}

\section{Pembahasan}

Berdasarkan gambar 1, hasil diskusi dari masing-masing kelompok yang telah disajikan pada lembar karton kemudian ditampilkan pada "pembeli" yaitu anggota kelompok lain yang akan singgah pada kelompok yang lainnya, dua orang anggota kelompok yang berperan sebagai tutor bertugas untuk menjelaskan hasil diskusi kepada kelompok yang berkunjung, sedangkan kelompok yang berkunjung akan mencatat hasil paparan materi dan diskusi selanjutnya menyampaikan pada anggota kelompoknya yang berperan sebagai tutor, hal ini terus berulang hingga masing-masing kelompok kembali pada kelompoknya, sehingga diharapkan semua mahasiswa memiliki pengetahuan dari semua materi yang disampaikan oleh masing-masing kelompok.

Model pembelajaran windows shopping bertujuan sebagai media yang menampung buah piker peserta didik yang akan disampaikan pada temannya yang lain dan sebaliknya, atau dikenal dengan istilah tutor sebaya, selain itu model pembelajaran ini dapat meningkatkan kemampuan komunikasi, percaya diri peserta didik, ketelitian serta kecermatan, hal ini merupakan kemampuan dasar yang harus dimiliki calon guru disamping kemampuan berpikir kritis dan manajemen waktu, sehingga dapat membuat suasana belajar menjadi menyenangkan dan memudahkan dalam penyampaian materi yang membutuhkan waktu relative lebih banyak terutama pada materi konsep dasar IPA, dengan menggunakan model pembelajaran ini pendidik dapat mengeksplorasi diri peserta didik di berbagai macam bidang ilmu terutama IPA (Yuhanna \& Retno, 2016).

Berdasarkan tabel 1, dapat terlihat bahwa pada kedua kelas baik kelas kontrol

\section{Pedagogika.fip@ung.ac.idＰ-ISSN: 2086-4469 E-ISSN: 2716-0580}


maupun mengalami peningkatan ketuntasan belajar sebelum dan sesudah proses belajar, hal ini menunjukkan bahwa proses pembelajaran dapat meningkatkan pengetahuan dari mahasiswa, hal ini sesuai dengan teori bahwa Pendidikan merupakan usaha sadar pendidik maupun instansi pendidikan untuk membuat suasana transfer ilmu dari pendidik kepada peserta didik menyenangkan demi meningkatkan kualitas peserta didik agar terwujudnya tujuan Pendidikan maupun tujuan pembelajaran yaitu mahasiswa memahami materi yang diberikan oleh pendidik.

Pada kelas perlakuan menggunakan model pembelajaran windows shopping terlihat peningkatan ketuntasan belajar yag signifikan yaitu dari 30\% mahasiswa yang tuntas dalam pembelajaran, menjadi $100 \%$ setelah diterapkan model pembelajaran windows shopping, sehingga model pembelajaran windows shopping dapat digunakan dalam upaya peningkatan ketuntasan belajar pada mahasiswa khususnya materi konsep dasar IPA, hal ini dapat terjadi karena dengan menggunakan tutor sebaya siswa akan lebih mudah memahami dan tidak canggung untuk bertanya jika ada materi yang belum dimengerti, diskusi antar kelompok juga dapat memberikan wawasan yang lebih kepada tiap peserta didik untuk memahami materi sehingga didapatkan kesamaan konsep pemahaman dari materi yang dipelajari.

Berdasarkan tabel 1, terdapat empat peserta didik yang tidak tuntas, sehingga dibutuhkan perhatian lebih terhadap peserta didik tersebut dengan cara penambahan jam belajar khusus peserta didik, pengayaan tambahan, upaya perbaikan nilai melalui remedial maupun penugasan sehingga tercapai ketuntasan belajar. Banyak faktor yang dapat mempengaruhi seorang peserta didik tidak tuntas dalam pembelajaran seperti suasana belajar dikelas yang kurang kondusif, maupun dari keaktifan dan faktor latar belakang siswa itu sendiri, hal ini sesuai dengan pendapat Zumroh et al., (2018) bahwa keberhasilan proses pembelajaran dapat dipengaruhi oleh faktor internal dan eksternal, dimana faktor yang ada dari dalam diri peserta didik yang meliputi kesehatan, minat, bakat, intelegensi dan motivasi dalam diri peserta didik yang masuk dalam kategori internal, sedangkan faktor eksternal merupakan pengaruh dari luar yang meliputi lingkungan kelas, sekolah dan keluarga (Rasidi \& Nuruddin, 2019).

Pada saat awal pembentukan kelompok diskusi menggunakan model pembelajaran windows shopping terdapat beberapa peserta didik yang masih terlihat pasif dan sebagian lainnya terlihat mendominasi jalannya diskusi, hal ini dapat disebabkan oleh beberapa factor diantaranya, fokus mahasiswa yang terpecah, beberapa siswa membutuhkan waktu beradaptasi dengan teman sekelompoknya, dan beberapa siswa yang lain membutuhkan waktu untuk memikirkan point-point apa saja yang harus ditampilkan pada saat proses windows shopping, sehingga kurangnya kerjasama antar kelompok (Herawati et al., 2019).

Menurut Indriwati et al., (2018) 
memancing siswa untuk bertanya dan mengemukakan pendapat ketika diskusi mampu membuat suasana diskusi menjadi menyenangkan sehingga dapat meningkatkan kemampuan komunikasi peserta didik dan tingkat percaya diri peserta didik, hal ini membuat masalah diawal diskusi dapat teratasi dan membuat proses diskusi lancar hingga akhir pembelajaran.

Berdasarkan hasil tabel 2, kelas perlakuan menggunakan model pembelajaran windows shopping pada materi konsep dasar IPA termasuk kategori tinggi dengan nilai rata-rata $\mathrm{N}$ gain sebesar 0.78 , sedangkan pada kelas kontrol masuk kedalam kategori sedang dengan niali ratarata $\mathrm{N}$ gain sebesar 0.50, hal ini menunjukkan bahwa penggunaan windows shopping berpotensi meningkatkan hasil belajar pada peserta didik.

Pada model pembelajaran windows shopping proses dan langkah-langkah pembelajarannya menuntut peserta didik lebih aktif baik dalam berdiskusi, maupun menyampaikan materi sebagai tutor sebaya untuk temannya yang lain sehingga terciptanya suasana belajar yang menyenangkan. Shopping atau 'berbelanja' dalam proses pembelajaran diasumsikan bahwa peserta didik diberi kebebasan berjalan-jalan melihat hasil kerja kelompok lain sehingga memberikan pengalaman baru bagi mereka untuk mengembangkan hasil kerjanya. Hal ini sesuai dengan teori kontruktivisme dimana teori Pendidikan yang megedepankan peningkatan perkembangan logika dan konseptual peserta didik, dengan berdiskusi dengan sesama peserta didik sehingga didapatkan rasa percaya diri, antusiasme dan interaksi tiap peserta didik sehingga membuat diskusi menjadi hidup dan suasana proses belajar menjadi menyenangkan, tujuan pembelajaran dapat tercapai dengan baik jika suasana kelas kondusif antara siswa dan guru (Santoso et al., 2018).

Pada tabel 2 dapat terlihat distribusi jumlah siswa yang mendapatkan peningkatan hasil belajar, pada kelas kontrol hanya $20 \%$ siswa yang mendapatkan peningkatan hasil belajar yang tinggi, sedangkan sebagian besarnya sebanyak $70 \%$ mendapatkan peningkatan hasil belajar sedang dan sisanya $10 \%$ rendah.

Beberapa faktor yang dapat mempengaruhi hal ini seperti faktor eksternal dan internal yang sudah dijelaskan sebelumnya serta penggunaan metode konvensional seperti ceramah memiliki banyak kelemahan selain membuat siswa tidak fokus, metode ini juga mudah menyebabkan kejenuhan pada siswa sehingga penyampaiyan materi yang diberikan menjadi tidak maksimal, selain iru banyaknya materi yang ada pada matakuliah Konsep Dasar IPA membuat pendidik sulit untuk mengkreasikan materi karena harus memenuhi semua materi untuk disampaikan, sehingga pembelajaran menjadi monoton dan hanya terfokus pada pendidik, hal ini membuat peserta didik menjadi pasif dan kurang responsif yang menyebabkan adanya peserta didik yang mendapatkan nilai rendah (Jarre \& Bachtiar, 2017).

Penerapan model pembelajaran 
windows shopping pada materi konsep IPA menunjukkan peningkatan hasil belajar yang signifikan dengan jumlah $70 \%$ peserta didik mendapatkan peningkatan hasil belajar yang tinggi dan sisanya $30 \%$ mendapatkan peningkatan hasil belajar yang sedang terhadap kelas kontrol, hasil ini dapat disebabkan karena pada model pembelajaran windows shopping menjadikan wawasan peserta didik berkembang karena pada prapembelajaran peserta didik, harus melakukan aktivitas literasi dan diskusi, yang dapat memunculkan sikap aktif, serius/fokus, bekerja sama antar peseta didik dalam kelompok diskusi, saat kerjasama tiap kelompok, menjadikan peserta didik mampu unjuk kreatif dalam menyusun hasil kerja yang nantinya, dijadikan sebagai media untuk kegiatan 'shopping', sehingga meningkatkan semangat dan aktivitas belajar peserta didik serta munculnya proses pembelajaran yang kondusif dapat menimbulkan rasa percaya diri siswa selaras dengan adanya kesempatan tanya jawab antar kelompok dan meningkatkan kemampuan interpersonal peserta didik maupun kemampuan kerjasama antar kelompok (Prasetyo \& Sasongko, 2014), sehingga menghasilkan kesamaan pemahaman konsep dari materi yang berdampak pada peningkatan hasil belajar yang tinggi dan menyeluruh pada seluruh siswa dikelas.

\section{SIMPULAN}

Penerapan model pembelajaran
windows shopping pada materi konsep dasar IPA dapat meningkatkan ketuntasan belajar pada siswa dan peningkatan hasil belajar serta menimbulkan sikap yang positif seperti, percaya diri, kemampuan interpersonal dan kerjasama kelompok.

\section{REFERENSI}

Dickey, E. M. (2013). Trends in International Mathematics and Science Study (TIMSS). Encyclopedia of Educational Reform and Dissent, $562-$

569.https://doi.org/10.4135/97814129 57403.n438

Herawati, L., Biologi, M. P., Pascasarjana, P., Bengkulu, U. M., Kritis, B., Reading, C. I., Team, S., \& Division, A. (2019). Pengaruh Model Pembelajaran Kooperatif Tipe Jigsaw Terhadap Hasil Belajar dan Berpikir Kritis Siswa Pada Mata Pelajaran IPA di SMP Negeri 09 Lebong. Prosiding Seminar Nasional Sains Dan Entrepreneunship Vi, 1-9. http://conference.upgris.ac.id/index.ph $\mathrm{p} / \mathrm{snse} /$ article/view/211

Indriwati, S. E., Susilo, H., \& Anggrella, D. P. (2018). Penerapan Model Pembelajaran Inkuiri Terbimbing Berbasis Lesson Study pada Matakuliah Keanekaragaman Hewan untuk Meningkatkan Kecakapan Komunikasi dan Hasil Belajar Kognitif Mahasiswa Pendidikan Biologi. Jurnal Pendidikan Biologi, 9(2), 38-46.

Jarre, A. R., \& Bachtiar, S. (2017). Aktivitas dan hasil belajar kognitif siswa meningkat melalui penerapan model jigsaw. Jurnal Biologi \& Pembelajarannya, 4(1), 26-33. https://ojs.unpkediri.ac.id/index.php/bi ologi/article/view/672/475 
Nurdjannah. (2019). Keaktifan, P., Hasil, D. A. N., \& Siswa, B. 2(2), 63-74.

Prasetyo, A. D., \& Sasongko, H. (2014). Aktivitas Antibakteri Ekstrak Etanol 96\% Kulit Buah Manggis (Garcinia mangostana L.) Terhadap Bakteri Shigella dysenteriae dan Bacillus subtilis Sebagai Materi Pelajaran Biologi SMA Kelas X untuk Mencapai Kompetensi Dasar 3.4 Kurikulum 2013. Jupemasi-Pbio, 1(1), 98-102.

Ramdani, A., Jufri, A. W., Jamaluddin, J., \& Setiadi, D. (2020). Kemampuan Berpikir Kritis dan Penguasaan Konsep Dasar IPA Peserta Didik. Jurnal Penelitian Pendidikan IPA, 6(1), 119. https://doi.org/10.29303/jppipa.v6i1.3 88

Rasidi, M. A., \& Nuruddin. (2019). Pengaruh Model Pembelajaran Kooperatif Tipe Windows Shopping Terhadap Keterampilan Berpikir Kritis Mahasiswa PGMI UIN Mataram. Jurnal Elementary, 2(2), 31-33.

Riyanto, P. (2019). Pengaruh Model Pembelajaran Jigsaw Terhadap Peningkatan Kemampuan Drible Bola Basket. Musamus Journal of Physical Education and Sport (MJPES), 2(01), 59-67.

https://doi.org/10.35724/mjpes.v2i01. 2069

SANTOSO, H., RIYANTO, P., \& ... (2018). Pengaruh Model Pembelajaran Tutor Sebaya (Peer Taeching) Terhadap Motivasi Belajar Pendidikan
Jasmani Siswa. ... Dan Ilmu Pendidikan, 4(02), 68-80. http://www.ejournal.unsub.ac.id/index .php/FKIP/article/view/289

Wihartanti, L. V. (2017). -Issn 2337-4721. Pendidikan Ekonomi UM Metro, 5(1), 37-46.

Yetti, R. (2018). Model Window Shopping Dalam Pembelajaran Membandingkan Teks Ulasan Film Pada Siswa Kelas $\mathrm{Xi}$ Tkr Smk Negeri 5 Pekanbaru. Journal on Education, 01(01), 75-82. http://www.jonedu.org/index.php/joe/ article/view/24

Yuhanna, W. L., \& Retno, R. S. (2016). the Learning of Science Basic Concept By Using Scientifiq Inquiry To Improve Student'S Thinking, Working, and Scientific Attitude Abilities. Jurnal Pendidikan Biologi Indonesia, 2(1), 1-9.

https://doi.org/10.22219/jpbi.v2i1.270 3

Yustiqvar, M., Gunawan, G., \& Hadisaputra, S. (2019). Green Chemistry Based Interactive Multimedia on Acid-Base Concept. Journal of Physics: Conference Series, 1364(1). https://doi.org/10.1088/17426596/1364/1/012006

Zumroh, N., Rahayu, E. S., \& Dewi, N. K. (2018). Keefektifan Model Pembelajaran Window Shopping dan Pendekatan Jelajah Alam Sekitar pada Materi Ekosistem. Journal of Biology Education, $\quad 7(2), \quad 221-225$. https://doi.org/10.15294/jbe.v7i2.2426 9 